\title{
Lack of Evidence for Involvement of P-Glycoprotein in Brain Uptake of the Centrally Acting Analgesic, Tramadol in the Rat
}

\author{
Behjat Sheikholeslami ${ }^{1}$, Mehrdad Hamidi ${ }^{2,{ }^{*}}$, Hoda Lavasani ${ }^{1}$, Mohammad Sharifzadeh $^{3}$, Mohammad-Reza Rouini ${ }^{1}$ \\ ${ }^{1}$ Biopharmaceutics and Pharmacokinetic Division, Department of Pharmaceutics, Faculty of Pharmacy, Tehran, \\ University of Medical Sciences, Tehran, Iran. \\ ${ }^{2}$ Department of Pharmaceutics, School of Pharmacy, Zanjan University of Medical Sciences, Zanjan, Iran. \\ ${ }^{3}$ Department of Pharmacology and Toxicology, Faculty of Pharmacy, Tehran University of Medical Sciences, \\ Tehran, Iran.
}

Received, July 24, 2012; Revised, October 20, 2012; Accepted, October 29, 2012; Published, November 5, 2012.

\begin{abstract}
Purpose. Tramadol Hydrochloride is a widely-used centrally acting analgesic drug, which has some features of being a P-gp substrate. The present study evaluates the functional involvement of Pgp in CNS distribution of tramadol. Methods. The possibe involvement of P-glycoprotein in brain distribution of tramadol was evaluated using a pharmacokinetic approach in two groups of Pgp-inhibited and control rats. Six male Sprague-Dawley rats were used in each group to collect plasma and brain at 1, 5,10 , and $30 \mathrm{~min}$ following two tramadol doses of 1 and $10 \mathrm{mg} / \mathrm{kg}$. Results. The brain uptake clearances of tramadol in Pgp-inhibited and control rats were $2.47 \pm 0.56$ and $2.34 \pm 0.56 \mathrm{ml} \mathrm{min}^{-1} \mathrm{~g}^{-1}$, respectively, for 1 $\mathrm{mg} / \mathrm{kg}$ and $3.50 \pm 0.60$ and $3.14 \pm 1.02 \mathrm{mlmin}^{-1} \mathrm{~g}^{-1}$, respectively, for $10 \mathrm{mg} / \mathrm{kg}$ dose. The brain-to-plasma concentration ratio (Kp,app) of more than 1 in all the time points following both the high and low dose cases (sometimes more than 3 ) indicated the brain accumulation of the drug. Linear correlation was found between tramadol dose and both corresponding plasma and brain concentrations, but the presence of a dose-dependency was not confirmed by the data obtained for brain-to-plasma concentration ratio. Conclusion. Considering the results of the previous studies and the present research, it seems that the brain accumulation of tramadol is not affected by P-gp inhibition which implies that there may be some other transport mechanisms involved in BBB transport of tramadol.
\end{abstract}

This article is open to POST-PUBLICATION REVIEW. Registered readers (see "For Readers") may comment by clicking on ABSTRACT on the issue's contents page.

\section{INTRODUCTION}

Blood brain barrier (BBB), is a very specialized endothelial structure located in capillaries distributed throughout the brain parenchyma.The existence of tight junctions between the brain capillary endothelial cells, the shortage of pinocytotic vesicles, the harmonized activity of a series of membrane transporters located in BBB, and the lack of fenestrations, collectively, cause a limited material transport across the BBB (1).The main role of BBB has, therefore, been defined as controlling, both physically and biochemically, the entrance of different molecules from systemic circulation to the central nervous system (CNS), thereby protecting this very sensitive organ from different biohazardous xenobiotics (2).

Transporters are membrane proteins which regulate the influx and/or efflux of the endogenous molecules and xenobiotics into/out of the cells (3). Considering the extensive distribution of different types of transporters throughout the body, these 'specialized gatekeepers' play remarkable while unique roles in drug pharmacokinetic/pharmacodynamic and distribution within the body (4-6). ABC superfamily consists of several genetically related transporters with apparently different biological functions, having prominent membrane transport activities in different tissues/cell types (3). P-glycoprotein (P-gp), the product of multidrug resistance (MDR) gene, is one of the most important members of the $\mathrm{ABC}$ superfamily (7). Its highly extensive tissue localization as well as different influx/efflux roles and, more importantly, a wide substrate specificity of different chemical and pharmacological classes cause this transporter to be in a central point of attention in pharmacokinetic studies (8-10).

Corresponding Author: Mehrdad Hamidi, Department of Pharmaceutics, School of Pharmacy, Zanjan University of Medical Sciences, Zanjan, Iran;

Email: hamidim@zums.ac.ir 
P-gp is a $170-k D a$ energy-dependent integral membrane protein which is encoded by by the $\mathrm{ABCB} 1$ and $\mathrm{ABCB} 2$ genes in human and mdrla, mdrlb and mdr2 genes in rodents $(11,12)$. Tissue distribution of P-gp has been studied extensively in human and rodents. The P-gp localization in the epithelial cells of GI tract, canalicular cells of the liver, placenta, kidney, and the BBB has been shown, both structurally and functionally, each having significant roles in pharmacokinetic profiles of different drugs (13, 14).

Several researches have focused on the effect of P-gp in the brain distribution of different CNS-active or CNS-reactive therapeutic agents with the key finding being the role of P-gp as an efflux transporter limiting the brain penetration of its substrates (15-17).

Tramadol hydrochloride, trans- $( \pm)-2-$ [(dimethylamino)methyl]-1-(3-meth-oxyphenyl) cyclohexanol, Hydrochloride) is a widely-used centrally acting analgesic drug,which is, infact, an opiate agonist. It also inhibits reuptake of norepinephrine and serotonin in synaptic junctions $(18,19)$. Tramadol is rapidly and extensively metabolized by hepatic O- and Ndesmethylation pathways catalyzed by cytochrome P-450 isoenzymes of 2D6, 2B6 and $3 \mathrm{~A} 4$, orderly (20). O-desmethyl tramadol (M1) and N-desmethyl tramadol (M2) are considered as main metabolites of the drug in humans. Chemically, tramadol has some features of being a P-gp substrate, mainly including the presence of planar aromatic domains and, in particular, tertiary amino groups (21). Therefore, functional interaction of P-gp and tramadol seems theoretically probable which, in turn, may have some important implications with respect to the drug pharmacokinetic, most importantly the involvement of P-gp at BBB level thus affecting the drug penetration to CNS.

There are, however, only few reports in literature focused on the neuropharmacokinetic of tramadol and the functional involvement of Pgp in this scenario. In a study using a Caco-2 cell monolayer model it has been demonstrated that tramadol enantiomers and its main metabolite, O-desmethyl tramadol, are not p-gp substrates (22); another study, contrarily, has pointed out that tramadol is one of the P-gp substrates (23). In this context, a well-controlled in vivo study in intact animal is needed seriously to solve this problem by clear experimental evidences obtained by direct measurement of the simultaneous drug concentrations in brain parenchyma and plasma, thereby estimation of the tissue uptake clearance in functionally P-gpinhibited as well as control animals.

Therefore, the present study uses such an approach to shed a light to the functional involvement of P-gp in CNS distribution of tramadol.

\section{MATERIAL AND METHODS}

\section{Materials}

Tramadol hydrochloride and cis-tramadol (internal standard) were generously supplied by Grünenthal (Stolberg, Germany). Verapamil hydrochloride was provided by Rouz Darou (Tehran, Iran). HPLC-grade acetonitrile and methanol, and analytical grade ethyl acetate and phosphoric acid (85\%) were from Merck (Darmstadt, Germany) and purchased locally. All other chemicals and solvents were of analytical grade and used without further purification.

\section{Animals}

Male Sprague-Dawley rats weighing between 250 and $300 \mathrm{~g}$ were housed in standard cages in a temperature- and humidity-controlled room with a $12 \mathrm{~h}$ light-dark cycle while they had free access to water and standard rat chow ad libitum. The whole animal study protocol was approved by the Institutional Review Board of Pharmaceutical Research Centre of Tehran University of Medical Sciences.

\section{Drug administration}

After general anesthesia by intraperitoneal (i.p.) injection of a ketamine-xylazine cocktail (ketamine $100 \mathrm{mg} / \mathrm{kg}$ and xylazine $10 \mathrm{mg} / \mathrm{kg}$ ), rats were catheterized using a polyethylenesilicone rubber catheter in their right jugular veins according to a standard surgical operation (24). Thereafter, animals were positioned apart from each other and left overnight for complete recovery. The day after, all of the animals, both P-gp-inhibited and control groups, received a dose of tramadol hydrochloride $(1,2.5,5$ and 10 $\mathrm{mg} / \mathrm{kg}$ of body weight) dissolved in a salineethanol vehicle $(1: 1 \mathrm{v} / \mathrm{v})$ via intravenous injection through the cannula. The P-gp-inhibited group of animals were also received two $1 \mathrm{mg} / \mathrm{kg}$ doses of verapamil hydrochloride $(1 \mathrm{mg} / \mathrm{ml})$ or quinidine sulphate $(15 \mathrm{mg} / \mathrm{ml})$ dissolved in a saline-ethanol vehicle $(1: 1, \mathrm{v} / \mathrm{v})$, as $\mathrm{p}$-gp inhibitors, through the same cannula $30 \mathrm{~min}$ before and concurrent with the tramadol dose. The control group (vehicle control) received the same dosage schedule except that the same volume of inhibitor-free vehicle was injected 
instead of inhibitor doses. The animals remained unrestrained during the entire drug administration and sampling periods.

\section{Sampling}

Each experiment group (P-gp-inhibited and control) was divided into subgroups of $1,5,10$ and $30 \mathrm{~min}$. Following the injection of tramadol dose, a 1-ml blood sample was obtained at predetermined time via the cannula to preheparinized polypropylene microtubes. Immediately after, animals were anesthetized by injection of an anesthetic cocktail (ketamine 10 $\mathrm{mg} / \mathrm{kg}$ and xylazine $1 \mathrm{mg} / \mathrm{kg}$ ) via the same cannula and decapitated immediately followed by removal of whole brain and brief rinsing it with saline and transferring it to ice-cold polypropylene containers and finally to $-20{ }^{\circ} \mathrm{C}$ freezer where it is kept until the drug analysis time. The blood samples were centrifuged at $1000 \mathrm{~g}$ for $10 \mathrm{~min}$ to separate the plasma which was kept frozen at $-20{ }^{\circ} \mathrm{C}$ until drug analysis time. Totally 132 rats were used throughout the experiments to collect 6 set of plasma and brain samples for each time point from each group.

\section{Drug assay}

The brains of the animals were defrosted, weighed and after adding saline $(1: 2 \mathrm{w} / \mathrm{v})$, homogenized using a high speed homogenizer (IKA, modelT 25 ULTRA-TURRAX, Germany) at a speed of $10,000 \mathrm{rpm}$ for $20 \mathrm{sec}$. For drug assay in these homogenates as well as in the plasma samples taken from the animals, a reversed-phase high performance liquid chromatography (HPLC) method with liquidliquid extraction and fluorescent detection was used throughout the study (25). In brief, to 120 $\mu 1$ of plasma or brain homogenate, $50 \mu \mathrm{NaOH}$ $(2 \mathrm{~N})$ and $50 \mu \mathrm{l}$ Cis Tramadol (internal standard; $1 \mu \mathrm{g} / \mathrm{ml}$ ) aqueous solutions were added. The mixture was vortex-mixed for $30 \mathrm{sec}$. Then, 1.2 $\mathrm{ml}$ ethylacetate was added in order to extract the drug from the biological matrices; the resulting mixture was shaken for $15 \mathrm{~min}$ and then centrifuged at $10000 \mathrm{~g}$ for $10 \mathrm{~min}$. The organic layer was transferred to a glass tube and evaporated to dryness under gentle air stream at $50{ }^{\circ} \mathrm{C}$. Finally, $120 \mu \mathrm{l}$ of mobile phase was added to reconstitute the samples by vortexmixing for $2 \mathrm{~min}$ and, finally, a $100 \mu \mathrm{l}$ aliquot was injected to chromatograph.

The chromatographic condition consisted of a double-reciprocating HPLC pump, a fluorescence detector set at the excitation wavelength $\left(\lambda_{\mathrm{ex}}\right)$ of $200 \mathrm{~nm}$ and the emission wavelength $\left(\lambda_{\mathrm{em}}\right)$ of $301 \mathrm{~nm}$ and an online degasser, all from Knauer (Berlin, Germany). A Rheodyne injector (model 7725i), equipped with a $100 \mu 1$ loop was used for sample injection. Data acquisition and processing were performed by means of compatible software (Knauer, ChromGate, Berlin, Germany). A mobile phase consisted of methanol and water (adjusted to $\mathrm{pH}$ 2.5 by phosphoric acid) $(19: 81 \mathrm{v} / \mathrm{v})$ was delivered in isocratic mode at $2 \mathrm{ml} / \mathrm{min}$ flow rate to a Chromolith ${ }^{\mathrm{TM}}$ Performance RP-18e column $(100 \mathrm{~mm} \times 4.6 \mathrm{~mm})$ (Merck, Darmstadt, Germany) protected by a Chromolith ${ }^{\mathrm{TM}}$ RP-18e Guard Cartridge $(5 \mathrm{~mm} \times 4.6 \mathrm{~mm}) \quad$ (Merck, Darmstadt, Germany).

\section{Pharmacokinetic analysis}

In order to have a parameter to primarily indicate the real-time drug uptake by the animal brains and also to differentiate the tissue drug uptake changes during the treatments from the possible effect(s) of experimental condition on the tramadol plasma concentration which, in turn, can influence the simultaneous tissue concentrations, the tissue-to-plasma concentrations ratio $\left(\mathrm{K}_{\mathrm{p}}\right)$ of tramadol was calculated for each time point in each animal from different groups. $\mathrm{K}_{\mathrm{p}}$ for each time point can be simply calculated as:

$$
K_{\mathrm{p}}=X_{(\mathrm{t})} / C_{\mathrm{p}(\mathrm{t})}
$$

where $\mathrm{X}_{(\mathrm{t})}$ and $\mathrm{C}_{\mathrm{p}(\mathrm{t})}$ are the simultaneous tissue and plasma concentrations of the drug at time $t$, respectively.

With the aim of estimating the drug clearance by the rat brain and, subsequently, the effect of P-gp inhibition on this process, the brain uptake clearance of tramadol following the intravenous administration to rats was defined. The rate of changes in the amount of drug in a tissue $\left(\mathrm{dX}_{(\mathrm{t})} / \mathrm{dt}\right)$ can be expressed as: (26)

$$
d X_{(\mathrm{t})} / d t=C l_{\text {uptake }} \cdot C_{\mathrm{p}(\mathrm{t})}
$$

Where; $\mathrm{Cl}_{\text {uptake }}$ represents the tissue uptake clearance of the drug.

Eq. (2) can be approximated as:

$$
\Delta X_{(\mathrm{t})} / \Delta t=C l_{\text {uptake }} \cdot C_{\mathrm{p}(\text { midpoint })}
$$

Where, $\Delta \mathrm{X}_{(\mathrm{t})}$ and $\Delta t$ indicate the changes in $\mathrm{X}_{(\mathrm{t})}$ and $\mathrm{t}$ between two sampling points, and $\mathrm{C}_{\mathrm{p} \text { (midpoint) }}$ is the mid-time drug plasma concentration between two successive time points. To solve the equation (3) for the time 
interval of 0 to $1 \mathrm{~min}$, since, on one hand, there is no drug amount in the brain at time zero (i.e., $\Delta \mathrm{X}_{(1)}$ equals to $\mathrm{X}_{(1 \mathrm{~min})}$ ) and $\Delta \mathrm{t}$ equals to $1 \mathrm{~min}$ for this interval, and, on the other hand, there is no significant change in drug plasma concentration within the short time interval of the first one minute of drug exposure (i.e., $\mathrm{C}_{\mathrm{p} \text { (midpoint) }} \approx$ $\left.\mathrm{C}_{\mathrm{p}(1 \mathrm{~min})}\right)$, one can conclude that :

$$
C l_{\text {uptake }}=X_{(1 \mathrm{~min})} / C_{\mathrm{p}(1 \mathrm{~min})}
$$

In other words, the tissue uptake clearance of the drug per gram of a tissue can be expressed as the ratio of the drug content per gram of tissue at time $1 \mathrm{~min}$ to the simultaneous plasma concentration, or:

$$
C l_{\text {uptake }} \approx K_{\mathrm{p}(1 \mathrm{~min})} .
$$

Considering the fact that the drug injection itself took 20 seconds to be completed and the blood sampling was done within 15 seconds, there was not practically possible to break the time to smaller portions below $1 \mathrm{~min}(8)$.

\section{Graphic estimation of the uptake clearance}

As an alternative possible approach, the integration plot analysis described by Hamidi (2007) was applied for graphic estimation of the uptake clearance of tramadol by the rat brain parenchyma (27). Integration of Eq. (2) yields:

$$
\mathrm{X}_{(\mathrm{t})}=\mathrm{Cl}_{\text {uptake }} \cdot \mathrm{AUC}_{0 \rightarrow \mathrm{t}}
$$

Where; $\mathrm{AUC}_{0 \rightarrow \mathrm{t}}$ is the area under the plasma concentration-time curve from time 0 to t. On the other hand, the following relationship defines the total amount of drug per unit mass of the brain at time $\mathrm{t}$ :

$$
\mathrm{X}_{\text {measured }(\mathrm{t})}=\mathrm{X}_{(\mathrm{t})}+\left(\mathrm{V}_{\text {vas }} \cdot \mathrm{C}_{\mathrm{p}(\mathrm{t})}\right)
$$

Where $\mathrm{X}$ measured(t) is the measured amount of drug per unit mass of the tissue at time $t$ and $\mathrm{V}_{\text {vas }}$ shows the volume occupied by the plasma within the brain vasculature per unit mass of the brain. By replacing the corresponding equivalent from Eq. (6) by $X_{(t)}$ in Eq. (7), followed by dividing the two sides of the Eq. (7) by $\mathrm{C}_{\mathrm{p}(\mathrm{t})}$, it can be rewritten as:

$$
\mathrm{X}_{(\mathrm{t})} / \mathrm{C}_{\mathrm{p}(\mathrm{t})}=\mathrm{Cl}_{\text {uptake }} \cdot \mathrm{AUC}_{0 \rightarrow t} / \mathrm{C}_{\mathrm{p}(\mathrm{t})}+\mathrm{V}_{\text {vas }}
$$

Therefore, by plotting the ratios of the drug concentrations in brain samples at time $t$ to the simultaneous plasma concentrations against the ratios of area under the plasma concentration- time curve from 0 to $\mathrm{t}$ to the corresponding plasma concentrations $\left(\mathrm{AUC}_{0 \rightarrow \mathrm{t}} / \mathrm{C}_{\mathrm{p}(\mathrm{t})}\right)$ (integration plot), a line will be obtained at the early time intervals, whose slope and y-intercept illustrate the apparent tissue uptake clearance and the volume of plasma in tissue vasculature per unit mass of the tissue, respectively (27).

\section{STATISTICAL ANALYSIS}

To distinguish the significant differences between the data pairs (P-gp inhibitor treated vs. the corresponding control) the statistical nonparametric Mann-Whitney test at a significance level of 0.05 was applied.

\section{RESULTS AND DISCUSSION}

To the best of our knowledge, there are few studies which have concerned about neuropharmacokinetic of tramadol and also its interaction with P-gp $(22,23,28,29)$. In addition, some controversies are evident between the few studies published in cell culture and human-based models. Therefore, in this study it was attempted, as described, to carry out a comprehensive neuropharmacokinetic study to describe the brain distribution of this centrallyacting drug quantitatively with the main focus on the role of P-gp in this scenario.

Verapamil is a well-known and widely-used calcium channel blocker with main therapeutic indications of hypertension, angina, and certain heart rhythm disorders. The ability of this drug in enhancing the tissue concentrations and effectiveness of other drug molecules via P-gp inhibition has been widely studied (30-32). In present study verapamil was used as a P-gp inhibitor regarding to the selectivity of the inhibitory action of the drug on P-gp compared to the cytochrome P450 isoenzyme 2D6, the main enzyme responsible for tramadol metabolism. The dose of verapamil was selected based on the expected plasma concentration and the $\mathrm{IC}_{50}$ of the inhibitor as well as the experiences in similar studies (33).

The plasma and brain concentrations of tramadol as well as the brain-to-plasma concentration ratios of the drug $\left(\mathrm{K}_{\mathrm{p}, \mathrm{app}}\right)$ at the early drug exposure time of 1 min have been indicated in Table 1 for four different doses of 1 , $2.5,5$, and $10 \mathrm{mg} / \mathrm{kg}$. To have a more realistic view about the drug partitioning behavior at different drug exposure levels of BBB, we decided firstly to evaluate the effect of different near-therapeutic doses of the drug on brain distribution of the drug in animals. 
As it is shown, the inhibitor has no significant effect on the plasma concentrations of the drug in all drug doses. This finding ensures that the possiblechanges in the brain concentrations of tramadol as a result of the coadministration of the drug with inhibitor can be attributed to the function of P-gp in BBB level, not the involvement of any factors working at pre-BBB level, e.g., inhibition of the drug metabolizing enzymes. The brain concentrations are, also, not affected significantly by the P-gp inhibition at any of the dosing levels. These concentrations, however, are not fully indicative of the brain penetration of the drug and we needed to calculate the simultaneous brain-toplasma concentration ratios of the drug at the corresponding time points. The $\mathrm{K}_{\mathrm{p}, \mathrm{ppp}}$ values shown in Table 1 indicate that, firstly tramadol is accumulated in brain parenchyma $\left(\mathrm{K}_{\mathrm{p}, \mathrm{app}}>1\right)$, and, secondly, this accumulation is not affected significantly by the P-gp inhibition at all doses tested.

In order to show the dose-dependency of the plasma and brain concentrations as well as the $\mathrm{K}_{\mathrm{p}, \text { app }}$ of the drug into brain, in Figures 1a to 1f, the linearity of all these pharmacokinetic parameters has been tested statistically and shown graphically using the linear regression test. As shown in Figures 1a $\left(\mathrm{R}^{2}=0.8716\right.$, $\mathrm{F}=128.96, \mathrm{P}=0.0001)$ and $1 \mathrm{~b}\left(\mathrm{R}^{2}=0.8611\right.$, $\mathrm{F}=124.01, \mathrm{P}=0.0001$ ), the plasma concentrations of tramadol at $1 \mathrm{~min}$ post-dose shows linear trend both in control and P-gp-inhibited groups. The brain concentrations in both groups, again, showed linear trend (Figure $1 \mathrm{c} ; \mathrm{R}^{2}=0.8604$, $\mathrm{F}=117.11, \mathrm{P}=0.0001$ ) (Figure $1 \mathrm{~d} ; \mathrm{R}^{2}=0.8438$, $\mathrm{F}=118.87, \mathrm{P}=0.0001)$. Finally, as shown in Figures $1 \mathrm{e}\left(\mathrm{R}^{2}=0.1722, \mathrm{~F}=3.28, \mathrm{P}=0.0869\right)$ and 1f $\left(\mathrm{R}^{2}=0.0927, \mathrm{~F}=4.65, \mathrm{P}=0.0434\right)$, the net brain entry of the drug, remained fairly constant abound the central mean values within the dose range tested, both in control and P-gp-inhibited group. This evidence indicates that, as expected, the brain-to-plasma concentration ratios of the drug is not dose-dependent, thus showing that no dose-related significant factor(s) affect the net brain entry to the drug within the dose range tested.

In order to evaluate the quantitative timecourse of the drug concentrations in plasma and brain and the $\mathrm{K}_{\mathrm{p}, \text { app }}$ values of the drug in rats, a cross-sectional pharmacokinetic study was carried out by drug administration to animals via the catheter inserted intravenously followed by plasma and brain sampling, as described, in a definite time post-dose. The pharmacokinetic approach used was such that a total of 6 rats were used to collect the data for each time point since the need for decapitation of animals does not allow any of the animals to survive for the further time points. The timecourse of plasma and tissue concentrations and $\mathrm{K}_{\mathrm{p}, \text { app }}$ of tramadol in the rats used in this part of the study are shown in Tables 2 and 3 for two different dosing levels of $1 \mathrm{mg} / \mathrm{kg}$ and $10 \mathrm{mg} / \mathrm{kg}$, respectively.

From the data it is evident that, firstly, the drug is accumulated in brain $\left(\mathrm{K}_{\mathrm{p}, \mathrm{app}}>1\right)$ in both dosing levels and all time points. Secondly, the brain accumulation increases to a plateau between 5 to $10 \mathrm{~min}$ and returns to its initial value at $30 \mathrm{~min}$. This trend results from the rapid fall in the plasma concentration of the drug (a two-compartment PK model) rather than any unexpected increase in brain concentration. However, this decrease in plasma concentration is smoothest beyond $10 \mathrm{~min}$. Thirdly; there is no significant difference between the P-gp-inhibited and control rats in all time points. This means that the involvement of P-gp in BBB transport of tramadol which was ruled out early in $1 \mathrm{~min}$ is not supported also by the rest of the later time pints data.

\begin{tabular}{|c|c|c|c|c|c|c|c|c|}
\hline \multirow{2}{*}{ Parameter } & \multicolumn{2}{|c|}{$1 \mathrm{mg} / \mathrm{kg}$} & \multicolumn{2}{|c|}{$2.5 \mathrm{mg} / \mathrm{kg}$} & \multicolumn{2}{|c|}{$5 \mathrm{mg} / \mathrm{kg}$} & \multicolumn{2}{|c|}{$10 \mathrm{mg} / \mathrm{kg}$} \\
\hline & Control & Treated & Control & Treated & Control & Treated & Control & Treated \\
\hline $\begin{array}{c}\text { Plasma } \\
\text { Conc. } \\
(\mathrm{ng} / \mathrm{ml})\end{array}$ & $\begin{array}{c}932.14 \\
\pm 307.36\end{array}$ & $\begin{array}{l}1195.04 \\
\pm 282.39\end{array}$ & $\begin{array}{l}2012.33 \\
\pm 663.16\end{array}$ & $\begin{array}{l}2763.22 \\
\pm 571.83\end{array}$ & $\begin{array}{c}5370.32 \\
\pm 1682.35\end{array}$ & $\begin{array}{c}5891.75 \\
\pm 1322.28\end{array}$ & $\begin{array}{l}11548.91 \\
\pm 2854.23\end{array}$ & $\begin{array}{c}9292.50 \\
\pm 2131.86\end{array}$ \\
\hline $\begin{array}{l}\text { Brain Conc. } \\
\quad(\mathrm{ng} / \mathrm{ml})\end{array}$ & $\begin{array}{l}2125.89 \\
\pm 765.89\end{array}$ & $\begin{array}{l}2720.84 \\
\pm 603.53\end{array}$ & $\begin{array}{l}5271.00 \\
\pm 790.56\end{array}$ & $\begin{array}{c}7353.35 \\
\pm 1762.96\end{array}$ & $\begin{array}{l}14794.85 \\
\pm 3166.66\end{array}$ & $\begin{array}{l}14416.49 \\
\pm 3409.78\end{array}$ & $\begin{array}{c}39423.52 \\
\pm 11644.40\end{array}$ & $\begin{array}{l}28277.48 \\
\pm 8217.87\end{array}$ \\
\hline $\mathrm{Kp}, \mathrm{app}$ & $\begin{array}{c}2.47 \\
\pm 0.56\end{array}$ & $\begin{array}{c}2.34 \\
\pm 0.56\end{array}$ & $\begin{array}{c}3.12 \\
\pm 1.39\end{array}$ & $\begin{array}{c}2.64 \\
\pm 0.36\end{array}$ & $\begin{array}{c}3.15 \\
\pm 0.97\end{array}$ & $\begin{array}{c}2.45 \\
\pm 0.18\end{array}$ & $\begin{array}{c}3.50 \\
\pm 0.60\end{array}$ & $\begin{array}{c}3.14 \\
\pm 1.02\end{array}$ \\
\hline
\end{tabular}



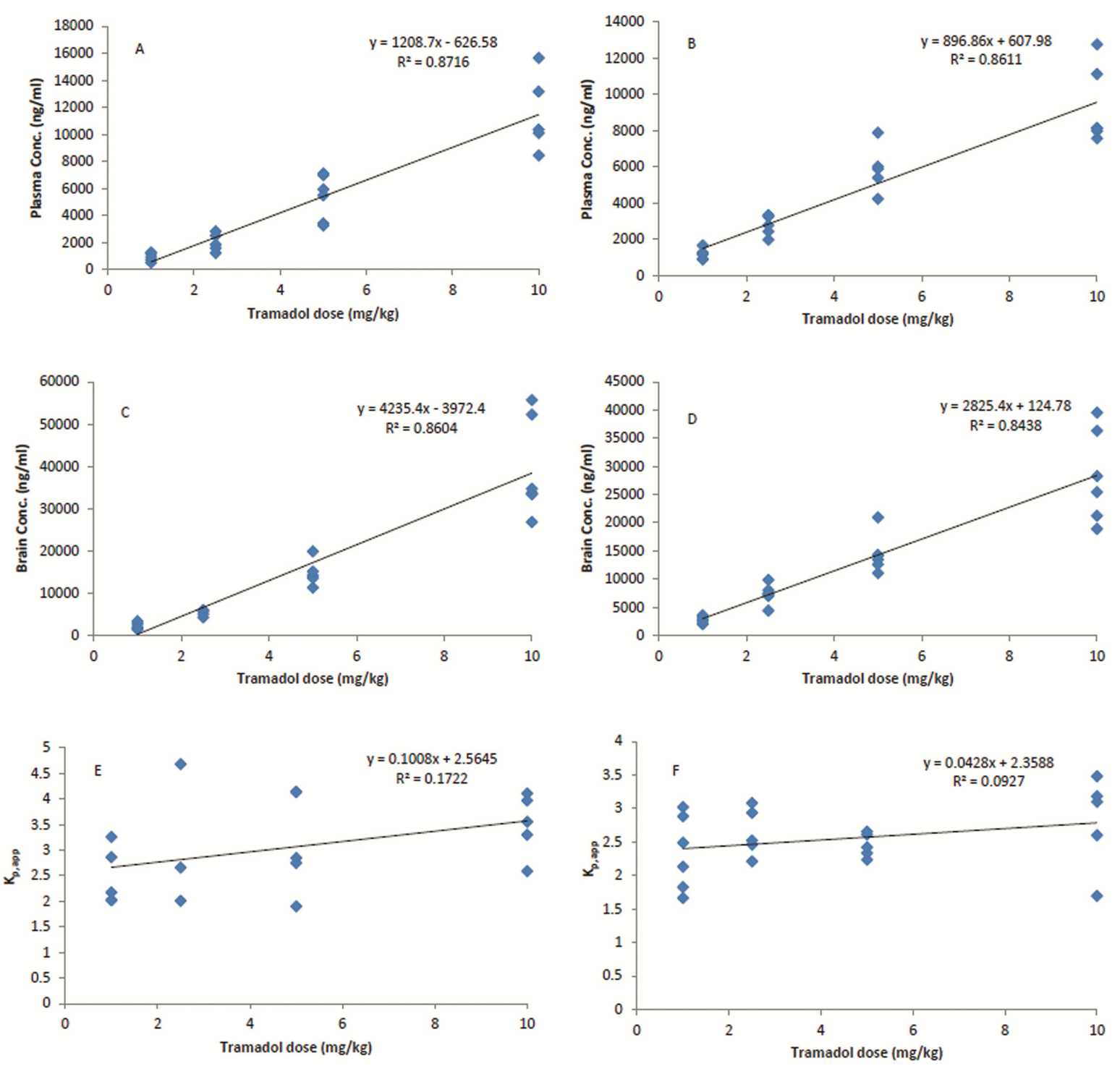

Figure 1. Dose dependency of plasma concentrations (a: control group, and b: P-gp (P-glycoprotein)-inhibited group), brain concentrations (c: control group, and d: P-gp-inhibited group), and Kp,app (e: control group, and f: Pgp-inhibited group) of tramadol 1 min post-dose in male Sprague-Dawley rats upon IV administration of different doses to animals.

Table 2. Plasma and brain concentrations and tissue-to-plasma concentration ratios (Kp,app) of tramadol in male Sprague-Dawley rats at 1,5, 10 and $30 \mathrm{~min}$ following a $1 \mathrm{mg} / \mathrm{kg}$ IV dose of tramadol hydrochloride coadministered with P-gp (P-glycoprotein) inhibitor (verapamil) or the vehicle (control). Data are presented as Mean \pm SD.

\begin{tabular}{ccccccccc}
\hline \multirow{2}{*}{ Tissue } & \multicolumn{2}{c}{$1 \mathrm{~min}$} & \multicolumn{2}{c}{$5 \mathrm{~min}$} & \multicolumn{2}{c}{$10 \mathrm{~min}$} & \multicolumn{2}{c}{$30 \mathrm{~min}$} \\
& Control & Treated & Control & Treated & Control & Treated & Control & Treated \\
\hline Plasma Conc. & 932.14 & 1195.04 & 377.72 & 433.86 & 358.62 & 370.77 & 210.14 & 215.84 \\
(ng/ml) & \pm 307.36 & \pm 282.39 & \pm 52.00 & \pm 70.32 & \pm 104.18 & \pm 84.68 & \pm 58.02 & \pm 49.67 \\
Brain Conc. & 2125.89 & 2720.84 & 2679.96 & 2736.89 & 2152.40 & 2676.32 & 678.60 & 686.57 \\
(ng/ml) & \pm 765.89 & \pm 603.53 & \pm 656.55 & \pm 311.00 & \pm 632.21 & \pm 610.05 & \pm 126.71 & \pm 108.62 \\
Kp, app & 2.47 & 2.34 & 7.33 & 6.48 & 6.51 & 7.43 & 3.30 & 3.23 \\
& \pm 0.56 & \pm 0.56 & \pm 1.50 & \pm 1.41 & \pm 2.78 & \pm 1.73 & \pm 0.41 & \pm 0.33 \\
\hline
\end{tabular}


Table 3. Plasma and brain concentrations (ng/ml) and tissue-to-plasma concentration ratios (Kp,app) of tramadol in male Sprague-Dawley rats at 1, 5, 10 and $30 \mathrm{~min}$ following a $10 \mathrm{mg} / \mathrm{kg} \mathrm{IV} \mathrm{dose} \mathrm{of} \mathrm{tramadol} \mathrm{hydrochloride} \mathrm{co-}$ administered with P-gp (P-glycoprotein) inhibitor (verapamil) or the vehicle (control). Data are presented as Mean \pm SD.

\begin{tabular}{ccccccccc}
\hline \multirow{2}{*}{ Tissue } & \multicolumn{2}{c}{$1 \mathrm{~min}$} & \multicolumn{2}{c}{$5 \mathrm{~min}$} & \multicolumn{2}{c}{$10 \mathrm{~min}$} & \multicolumn{2}{c}{$30 \mathrm{~min}$} \\
& Control & Treated & Control & Treated & Control & Treated & Control & Treated \\
\hline Plasma & 11548.91 & 9292.50 & 5496.99 & 3669.38 & 3772.74 & 2368.70 & 2084.04 & 2295.36 \\
Conc. & \pm 2854.23 & \pm 2131.86 & \pm 2226.26 & \pm 1589.58 & \pm 1109.37 & \pm 621.43 & \pm 944.71 & \pm 445.86 \\
(ng/ml) & & & & & & & & \\
Brain Conc. & 39423.52 & 28277.48 & 21215.21 & 17638.36 & 17724.05 & 14166.70 & 6306.14 & 5177.58 \\
(ng/ml) & \pm 11644.40 & \pm 8217.87 & \pm 3996.35 & \pm 4275.82 & \pm 4003.03 & \pm 3007.24 & \pm 845.04 & \pm 807.06 \\
& & & & & & & & \\
Kp, app & 3.50 & 3.14 & 4.17 & 5.59 & 4.99 & 5.84 & 3.57 & 2.38 \\
& \pm 0.60 & \pm 1.02 & \pm 0.90 & \pm 2.33 & \pm 1.65 & \pm 1.52 & \pm 1.57 & \pm 0.45 \\
\hline
\end{tabular}

For the purpose of estimating the brain uptake clearance of tramadol, initially, a graphical approach was used as described earlier in this paper. The basis for this analysis is the linear correlation between the ratio of the area under the plasma concentration time curve from zero to a given time to the corresponding plasma concentration ( $\mathrm{x}$ ) and the $\mathrm{K}_{\mathrm{p} \text {,app }}$ of the drug at that time point $(\mathrm{y})$. The slope of such a plot represents the tissue uptake clearance and the yintercept is an estimate of the space occupied by the plasma circulating in brain microvasculature. If the drug transport from blood to the brain parenchyma is mainly unidirectional during the time interval tested, i.e., the influx is predominant, this plot will be an ascending line. If this assumption does not exist, i.e., the efflux is significant at the same time, the plot will not be a line. As shown in Figure2, the results of the integration plot analysis were not linear in the current study for both high $(10 \mathrm{mg} / \mathrm{kg})$ and low $(1 \mathrm{mg} / \mathrm{kg})$ dosing levels. Therefore, this approach could not be used for the estimation of the brain uptake clearance of tramadol.

To solve the above-mentioned problem, a single-point approach was used in this study, as described earlier in this paper, using the data collected only in $1 \mathrm{~min}$ time point. In Table 4, the brain uptake clearance by the rats in both control and P-gp-inhibited groups for both 1 $\mathrm{mg} / \mathrm{kg}$ and $10 \mathrm{mg} / \mathrm{kg}$ doses are shown. From the data in Table 4, it is evident that the uptake clearance of tramadol by brain parenchyma undergoes no significant change upon P-gp inhibition in rats. Also, there is a slight increase, marginally significant, in uptake clearance of the drug by brain by increasing the dose from 1 to 10 $\mathrm{mg} / \mathrm{kg}$, which can be explained by some minor auto-inhibition of the drug efflux from the brain back to the blood circulation or, alternatively, some auto-inducible component(s) in drug influx from blood to brain. The validity of one or a combination of these two possibilities remains to be evaluated experimentally by further studies.

Different explanations may be postulated for the lack of significant effect of verapamil on tramadol brain penetration. First, it would be assumed that there is no interaction between Pgp and tramadol in BBB, which is in agreement with the results of Mouna Kanaanet al (22) and contrary to the data published by Ondřej Slanařet al (23). Second, verapamil (at least in the applied dose) could not inhibit the brain efflux of tramadol by P-gp. Third, the applied tramadol dose is high enough to saturate the efflux transporters, a phenomenon which has previously reported for other drugs (34).

To ensure the presence of enough concentration of verapamil as P-gp inhibitor, the dose of verapamil was increased from 1 to 5 $\mathrm{mg} / \mathrm{kg}$ in P-gp-inhibition group with the tramadol dose kept constant at $1 \mathrm{mg} / \mathrm{kg}$. Our results at early exposure time of $1 \mathrm{~min}$ did not show any distinctive difference in tramadol brain $\mathrm{K}_{\mathrm{p}, \mathrm{app}}$ when the dose of verapamil was increased to $5 \mathrm{mg} / \mathrm{kg}$ (Table 5). It has been shown that Pgp has more than one drug binding sites so that the P-gp inhibition is substrate-dependent (35). The dependency of verapamil P-gp inhibition to the chemical structure of substrate has been shown by Zolinerciks et al (35). To test this possibility, a set of the P-gp inhibition test was carried out, as described, using another welldocumented P-gp inhibitor, quinidine, in a dose of $15 \mathrm{mg} / \mathrm{kg}$ and the brain penetration of tramadol was determined at $1 \mathrm{~min}$ after the injection of tramadol in a dose of $1 \mathrm{mg} / \mathrm{kg}$. The dose of quinidine used in this study was selected 
based on our experiences with this inhibitor during three other projects (36-38) which were indicative of the significant functional inhibition of P-gp with the same weight-based dose of quinidine. There was no significant difference between quinidine-treated and control groups (Table 5). Accordingly, we concluded that neither quinidine nor verapamil have any significant effect on the brain uptake of tramadol. Therefore, the involvement of P-gp in BBB transport of tramadol can be ruled out, more strongly supported by the data in Table 5 . The third possibility, i.e., the saturation of P-gp by the high tramadol concentrations was already rejected by comparing the data obtained with 1 and $10 \mathrm{mg} / \mathrm{kg}$ doses of tramadol (Tables 2 and $3)$.

\section{CONCLUSION}

A pharmacokinetic study was carried out in intact rats to estimate the brain uptake clearance of tramadol and, then, the possible involvement of P-gp in the brain distribution of the drug. From the data, it is obvious that tramadol is unrestrictedly penetrates the brain parenchyma with about 2 to 6 -fold drug accumulation in brain at different time points.
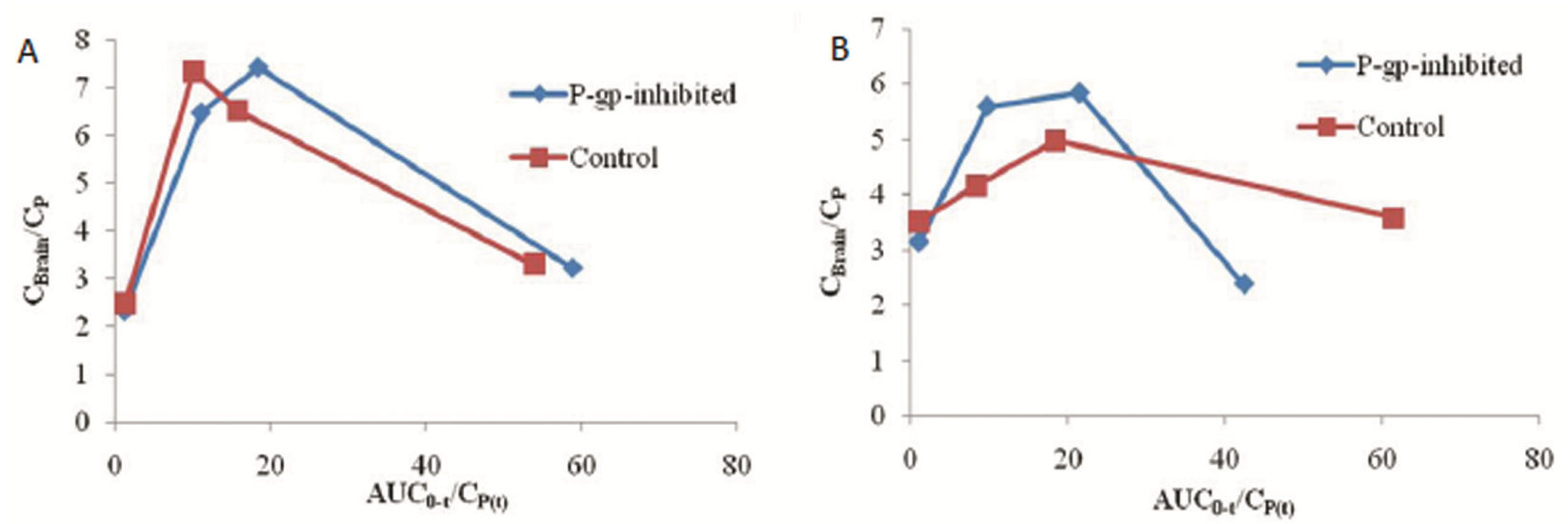

Figure 2. Integration plots of tramadol in the rat brain in P-gp (P-glycoprotein)-inhibited as well as control rats (a: tramadol dose of $1 \mathrm{mg} / \mathrm{kg}$ and b:tramadol dose of $10 \mathrm{mg} / \mathrm{kg}$ )

Table 4. Brain uptake clearance $\left(\mathrm{Cl}_{\text {uptake }}\right)$ of of tramadol in male Sprague-Dawley rats at two dose levels of $1 \mathrm{mg} / \mathrm{kg}$ and $10 \mathrm{mg} / \mathrm{kg}$ in both P-gp (P-glycoprotein)-inhibited and control groups. Data are presented as Mean \pm SD.

\begin{tabular}{ccccc}
\hline \multirow{2}{*}{ PK parameter } & \multicolumn{2}{c}{$1 \mathrm{mg} / \mathrm{kg}$} & \multicolumn{2}{c}{$10 \mathrm{mg} / \mathrm{kg}$} \\
& Control & Treated & Control & Treated \\
\hline $\mathrm{Cl}_{\text {uptake }}\left({\left.\mathrm{m} l \mathrm{~min}^{-1} \mathrm{~g}^{-1}\right)}^{2.47 \pm 0.56}\right.$ & $2.34 \pm 0.56$ & $3.50 \pm 0.60$ & $3.14 \pm 1.02$ \\
\hline
\end{tabular}

Table 5. Plasma and brain concentrations and brain-to-plasma concentration ratios $\left(\mathrm{K}_{\mathrm{p} \text {,app }}\right)$ of tramadol in male Sprague-Dawley rats at $1 \mathrm{~min}$ following a $1 \mathrm{mg} / \mathrm{kg}$ IV dose of tramadol hydrochloride co-administered with P-gp (P-glycoprotein) inhibitors verapamil or quinidine or the vehicle (control). Data are presented as Mean \pm SD.

\begin{tabular}{ccccc}
\hline & Control & $\begin{array}{c}\text { Verapamil-inhibited } \\
(1 \mathrm{mg} / \mathrm{kg})\end{array}$ & $\begin{array}{c}\text { Verapamil-inhibited } \\
(5 \mathrm{mg} / \mathrm{kg})\end{array}$ & $\begin{array}{c}\text { Quinidine-inhibited } \\
(15 \mathrm{mg} / \mathrm{kg})\end{array}$ \\
\hline Plasma Conc. & 932.14 & 1195.04 & 1209.74 & 1597.08 \\
(ng/ml) & \pm 307.36 & \pm 282.39 & \pm 180.65 & \pm 525.11 \\
Brain Conc. & 2125.89 & 2720.84 & 3302.84 & 2449.00 \\
$(\mathrm{ng} / \mathrm{ml})$ & \pm 765.89 & \pm 603.53 & \pm 1342.25 & \pm 588.67 \\
Kp, app & 2.47 & 2.34 & 2.54 & 1.80 \\
& \pm 0.56 & \pm 0.56 & \pm 0.81 & \pm 0.88 \\
\hline
\end{tabular}


Nonetheless, if, hypothetically, the involvement of some P-gp-related components in BBB transport of this widely used drug was evident by the data in the present study, there would be a potential for achievement of even more drug concentrations in the brain. The data collected showed, however, that the P-gp inhibition by verapamil, a well-known P-gp inhibitor, has no discernible effect on brain penetration of the drug. The effect of the type or concentration of the inhibitor as well as any influence of the different tramadol concentrations in vicinity of the transporter, on the interaction between P-gp and tramadol at BBB level were all ruled out by the clear evidences from this study.

\section{ACKNOWLEDGMENTS}

This study was part of a $\mathrm{PhD}$. thesis fully supported by Tehran University of Medical Sciences (grant No. 7758). Authors wish to thank Dr. Ali Shafiei and Mr. Gholami for their kind assistance.

\section{REFERENCES}

1. Doze P, Van Waarde A, Elsinga PH, Hendrikse NH, Vaalburg W. Enhanced cerebral uptake of receptor ligands by modulation of P-glycoprotein function in the blood-brain barrier. Synapse,2000; 36: 66-74.

2. Lai CH, Kuo KH, Leo JM. Critical role of actin in modulating BBB permeability. Brain Res Brain Res Rev, 2005; 50: 7-13.

3. Guofeng Y, Marilyn EM, Binghe W. Drug Transporters: Molecular Characterization and Role in Drug Disposition. Wiley-Interscience: New York, 2007.

4. Hammarlund-Udenaes M, Paalzow LK, de Lange EC. Drug equilibration across the blood-brain barrier--pharmacokinetic considerations based on the microdialysis method. Pharm Res, 1997; 14: 128-134.

5. Syvänen S, Xie R, Sahin S, HammarlundUdenaes M. Pharmacokinetic consequences of active drug efflux at the blood-brain barrier. Pharm Res, 2006; 23: 705-717.

6. Golden PL, Pollack GM. Rationale for influx enhancement versus efflux blockade to increase drug exposure to the brain. Biopharm Drug Dispos, 1998; 19: 263-272.

7. Mizuno N, Niwa T, Yotsumoto Y, Sugiyama Y. Impact of drug transporter studies on drug discovery and development. Pharmacol Rev, 2003; 55: 425-461.

8. Brinkmann U. Functional polymorphisms of the human multidrug resistance (MDR1) gene: correlation with $\mathrm{P}$ glycoprotein expression and activity in vivo. Novartis Found Symp, 2002; 243: 207-210.
9. Fromm MF. Importance of P-glycoprotein at blood-tissue barriers.Trends Pharmacol Sci, 2004; 25: 423-429.

10. Fromm MF. Importance of P-glycoprotein for drug disposition in humans. Eur J Clin Invest, 2003; 33 (Suppl. 2): 6-9.

11. Ling V. Multidrug resistance: molecular mechanisms and clinical relevance. Cancer Chemother Pharmacol, 1997; 40 (Suppl.): S3-S8.

12. Lee G, Dallas S, Hong M, Bendayan R. Drug transporters in the central nervous system: brain barriers and brain parenchyma considerations. Pharmacol Rev, 2001; 53: 569-596.

13. Hamidi M. Role of P-glycoprotein in tissue uptake of indinavir in rat. Life Sci, 2006; 79: 991-998.

14. Schinkel AH, Jonker JW. Mammalian drug efflux transporters of the ATP binding cassette (ABC) family: an overview. Adv Drug Deliv Rev, 2003; 55: 3-29.

15. Uhr M, Grauer MT. abcblab P-glycoprotein is involved in the uptake of citalopram and trimipramine into the brain of mice. J Psychiatr Res, 2003; 37: 179-185.

16. Uhr M, Grauer MT, Yassouridis A, Ebinger M. Blood-brain barrier penetration and pharmacokinetics of amitriptyline and its metabolites in p-glycoprotein (abcblab) knockout mice and controls. J Psychiatr Res, 2007; 41: 179-188.

17. Karlsson L, Schmitt U, Josefsson M, Carlsson B, Ahlner J, Bengtsson F, Kugelberg FC, Hiemke C. Blood-brain barrier penetration of the enantiomers of venlafaxine and its metabolites in mice lacking P-glycoprotein. Eur Neuropsychopharmacol, 2010; 20: 632-640.

18. Dayer P, Collart L, Desmeules J. The pharmacology of tramadol. Drugs, 1994; 47 (Suppl 1): 3-7.

19. Poulsen L, Arendt-Nielsen L, Brøsen K, Sindrup $\mathrm{SH}$. The hypoalgesic effect of tramadol in relation to CYP2D6. Clin Pharmacol Ther, 1996; 60: 636-644.

20. Budd K, Langford R. Tramadol revisited. Br J Anaesth, 1999; 82: 493-495.

21. Seelig A, Landwojtowicz E. Structure-activity relationship of P-glycoprotein substrates and modifiers. Eur J Pharm Sci, 2000; 12: 31-40.

22. Kanaan M, Daali Y, Dayer P, Desmeules J. Uptake/efflux transport of tramadol enantiomers and O-desmethyl-tramadol: focus on Pglycoprotein. Basic Clin Pharmacol Toxicol, 2009; 105: 199-206.

23. Slanar O, Nobilis M, Kvétina J, Matousková O, Idle JR, Perlík F. Pharmacokinetics of tramadol is affected by MDR1 polymorphism C3435T. Eur J Clin Pharmacol, 2007; 63: 419-421.

24. Waynforth HB, Flecknell PA. Experimental and Surgical Techniques in the Rat, 2nd edn. Academic Press: London, 1992.

25. Ardakani YH, Rouini MR. Improved liquid chromatographic method for the simultaneous 
determination of tramadol and its three main metabolites in human plasma, urine and saliva. J Pharm Biomed Anal, 2007; 44: 1168-1173.

26. Shargel L, Wu-PongS, Yu A. Applied Biopharmaceutics and Pharmacokinetics, 5th edn. McGraw-Hill Medical: New York, 2004.

27. Hamidi M. Central nervous system distribution kinetics of indinavir in rats. J Pharm Pharmacol, 2007; 59: 1077-1085.

28. Tao Q, Stone DJ, Borenstein MR, Codd EE, Coogan TP, Desai-Krieger D, Liao S, Raffa RB. Differential tramadol and O-desmethyl metabolite levels in brain vs. plasma of mice and rats administered tramadol hydrochloride orally. J Clin Pharm Ther, 2002; 27: 99-106.

29. Allegaert K, de Hoon J, Verbesselt R, Devlieger H, Tibboel D. Tramadol concentrations in blood and in cerebrospinal fluid in a neonate. Eur J Clin Pharmacol, 2005; 60: 911-913.

30. Sakugawa T, Miura M, Hokama N, Suzuki T, Tateishi T, Uno T. Enantioselective disposition of fexofenadine with the P-glycoprotein inhibitor verapamil. Br J Clin Pharmacol, 2009; 67: 53540.

31. Bansal T, Mishra G, Jaggi M, Khar RK, Talegaonkar S. Effect of P-glycoprotein inhibitor, verapamil, on oral bioavailability and pharmacokinetics of irinotecan in rats. Eur $\mathrm{J}$ Pharm Sci, 2009; 36: 580-590.

32. Choi JS, Li X. The effect of verapamil on the pharmacokinetics of paclitaxel in rats. Eur $\mathrm{J}$ Pharm Sci, 2005; 24: 95-100.
33. Marier JF, Deschênes JL, Hage A, Seliniotakis E, Gritsas A, Flarakos T, Beaudry F, Vachon P. Enhancing the uptake of dextromethorphan in the CNS of rats by concomitant administration of the P-gp inhibitor verapamil. Life Sci, 2005; 77: 2911-2926.

34. Cisternino S, Bourasset F, Archimbaud Y, Sémiond D, Sanderink G, Scherrmann JM. Nonlinear accumulation in the brain of the new taxoid TXD258 following saturation of Pglycoprotein at the blood-brain barrier in mice and rats. Br J Pharmacol, 2003; 138: 1367-1375.

35. Zolnerciks JK, Booth-Genthe CL, Gupta A, Harris J, Unadkat JD. Substrate- and speciesdependent inhibition of P-glycoprotein-mediated transport: implications for predicting in vivo drug interactions. J Pharm Sci, 2011; 100: 3055-3061.

36. Sahraei MA. Role of P-glycoprotein in neuropharmacokinetic of phenytoin in rat. Pharm. D. Thesis, No. 287, faculty of pharmacy, Shiraz university of medical sciences, Shiraz, Iran. 2006

37. Majidi L. effect of acute and chronic inflammation on the functional role $\mathrm{P}$ glycoprotein in Blood-Brain Barrier. Pharm. D. Thesis, No. 328, faculty of pharmacy, Shiraz university of medical sciences, Shiraz, Iran. 2010.

38. Aryanpour Z. The effect of P-glycoprotein on neuropharmacokinetic of phenytoin at acute seizure rat. Pharm. D. Thesis, No. 357, faculty of pharmacy, Shiraz university of medical sciences, Shiraz, Iran. 2009. 